DOI: $10.17805 /$ zpu.2016.1.29

\title{
Enlightenment from the East: Early Nineteenth Century Russian Views of the East from Kazan University
}

\author{
S. SMITH-PETER \\ (CITY UNIVERSITY OF NEW YORK, USA)
}

This article examines why certain authors saw the East as both self and Other in the first years of the existence of Kazan University (est. 1804). During this time, the Oriental Renaissance saw the East as the source of knowledge and light, resulting in a more positive view of the East than in the late nineteenth century, when imperialism and hostile European views of the East reached Russia. The older generation of Kazan authors of the 1810s were influenced by Catherinian-era classicism, and adapted tropes from that time, bringing the East back into the center of Russian affairs and celebrating the mixture of East and West. The younger generation was more influenced by sentimentalism and saw the East as separate from the self, but still close to home. These authors deepen our understanding of the interconnections between Russia and the East at the institutional, intellectual, and individual levels.

Keywords: Orientalism; Russia between East and West; Kazan University; Russian literature; Sergei Aksakov; Tatars

$\mathrm{T}$ his article explores the development of a regional identity in early nineteenth century Kazan, a university town on the Volga River 495 miles southeast of Moscow with a rich multiethnic history. In 1804, Kazan University was founded along with the Kazan Educational District; both would play a key role in fostering the idea of Eastern Russia as a region. Since Ivan the Terrible conquered the Kazan Khanate in 1552, the town has been a major point of contact between Russians, Tatars, a Muslim Turkic people with a long tradition of learning, and other ethnic groups. In the early nineteenth century, local intellectuals argued that Kazan was the capital of Eastern Russia, a massive region encompassing the Volga region, the Urals, and Siberia. This paper argues that the East became a source for individual, group and regional identities in the region of Kazan in the early nineteenth century. The East could stand both for the self and the Other.

Established in 1804, Kazan University served as a window on the East from its inception (Geraci, 2001). It was designated the center of study for Asian languages and cultures and it published in Tatar, Arabic, Persian and Turkish languages for the empire as a whole (Mikhailova, 1991, 1997). During the early nineteenth century, Russians shared in the general European "Oriental Renaissance" that envisioned Asia as a civilization marked by "high moral principles, enduring veneration of tradition, and intellectual enlightenment" (Bassin, 1999: 49). These new ideas infused a new regional vision of Kazan as the capital of Eastern Russia.

The territorial framework for imagining Eastern Russia was the Kazan Educational District, encompassing Russia's fifteen easternmost provinces from Kazan to Kamchatka, roughly 2980 miles wide. This emerging sense of place emphasized the culturally distinct characteristics of Eastern Russia, including its multiethnic population, its closeness to Asia, and its status as a capital equal to Moscow and St. Petersburg. The sources used in this article are the rich but understudied corpus of published and archival provincial periodicals and almanacs produced in Kazan and its educational district between 1804, when Kazan University was founded, and 1825, when the ascension of Nicholas I (reigned 1825-1855) substantively changed the conditions for publishing.

The creation of Kazan University marked the introduction of a powerful institution in the region dedicated to its study. As a result of this new institution, a new vision of regional 
Russia emerged, with the vast spaces of Eastern Russia contrasted to the smaller core of European Russia. Teachers and administrators trained at Kazan University were sent to schools throughout the Kazan Educational District. These educators would then send reports on the history, culture, ethnography, and economies of their area to the heads of the educational district, to be published in the university's journals. This created a community bound by education and profession as well as a commitment to the imagined community of Eastern Russia. At the same time, sentimentalism and Romanticism turned authors inward, and the search for the self and for the East became intertwined.

Kazan University has attracted a great deal of scholarly attention. The pre-revolutionary literature is rich in sources but mainly descriptive (Bulich, 1887; Zagoskin, 1902). Soviet histories included quite a bit on the university's role in studying the nationalities, as have Western works. The frame has therefore often been nationalities policy, not regional identity (Mikhailova, 1979, 1991; Geraci, 2001). Other works have dealt with the early years of Kazan University from an institutional point of view, while others deal with Kazan within the framework of regional studies (kraevedenie) (Smith-Peter, 2004), which limits the scope to Kazan and its province alone (Aristov, 1987; Druzhinina, 2006; Flynn, 1988; Garzavina, 1987; Mikhailova, Korshunova, 2006; Schimmelpenninck van der Oye, 2004; Vishlenkova, 2003). Thus, none of the large bodies of work on Kazan and Kazan University deal with its early role in encouraging new ideas about Russia's place vis-a-vis the East, although there are works that refer to the university's role in stimulating Siberian regional identity through the work of regionalist historian A. P. Shchapov in the 1850s and early 1860 s (Hagen von, 2007; Mohrenschildt von, 1981). In contrast, this work will investigate how authors active in Kazan created a sense of the East that was both close and distant, strange and familiar.

More broadly, this work contributes to the debate over Russia's attitude toward the East and over the existence and characteristics of a Russian Orientalism. Orientalism has been defined by Edward Said as "a Western style for dominating, restructuring, and having authority over the Orient" by producing knowledge about it backed by political, social and military power (Said, 1979: 3). Such knowledge used the Other of the Orient as inferior and, often, female, to shore up a sense of self as Western, superior and male. However, in the case of Russia, as Susan Layton has noted, "the cognitive boundary between 'us' and the Oriental 'others' often blurred because Asia interpenetrated Russia so extensively in geographical, historical, and cultural terms" (Layton, 1997: 82). Nathaniel Knight writes that the "stark dichotomy between Orient and Occident around which Said's analysis hinges transforms in the Russian context into an awkward triptych: the West, Russia, the East. Russia, after all, was not only the subject of orientalist discourse, but also its object" (Knight, 2000: 77)1. Larry Wolff has brilliantly shown how Western Europe constituted itself during the Enlightenment as rational and male by contrasting itself to Eastern Europe, which was portrayed as irrational, weak, and female (Wolff, 1994). Thus, Eastern Europe itself was the object of a form of orientalism. At times, as with Russian travelogues on Iran, this uncertain Russian identity could lead to rejection of the East as a sort of suppressed self, along with an exaggerated identification with Europe, particularly Britain (Andreeva, 2007)2. However, another possibility was a more nuanced appreciation of the East, especially within the boundaries of Russia, where it was less threatening. As Susan Layton notes, "a Russian could not believe in the alterity of the Orient as readily and invariably as a European might," which gave Russian Romantics "a stake in enhancing Asia rather than consistently acclaiming the western civilization in which they knew they did not fully belong" (Layton, 1994: 
74-75). Russian Orientalism, although it existed as a system of knowledge and power, was not the same as Western European Orientalism; for Russia, the East was both self and other.

From Kazan, the former capital of the Khanate of Kazan, the East looked different than it did from London or Berlin. For an older generation of authors, following the traditions of the era of Catherine the Great (r. 1762-1796), the East was both self and Other, while the younger generation used Eastern tropes as a terrain on which to project sentimentalist reflections. For scholars at Kazan University, Eastern Russia provided a vast landscape for scholarly investigations, with Kazan as the head and coordinating center. Although the East was a place for scholarly study, it was also the source of identity as a resident of Eastern Russia. Far from the idea that "never the twain shall meet," in the words of Alexander Herzen, in Kazan "there are two origins: western and eastern, and one meets them on every street corner; here from constant activity they got used to each other, became friends, and began to form something original in character" (Garzavina, Novitskii, 1984: 48)³.

\section{KAZAN AS PLACE AND IDEA}

Kazan was originally settled by the Volga Tatars. The name comes either from the Volga Tatar word qazan for kettle or the Chuvash xosan meaning bend, for the nearby bend of the Volga. The Bulgars, a Turkic people whose state, Bulgar, had been sacked by the Mongols in the 1236, founded a successor state named Iski Kazan later in the thirteenth century. In the early fifteenth century it was moved to where Kazan is today, and in 1445, the khanate of Kazan was founded by the Tatars, who are generally seen as the successors of the Bulgars, and became involved in a struggle for power between Muscovy and the khanate of Crimea (Ostrowski, 2004: 732).

Ivan the Terrible's conquest of Kazan in 1552 is generally considered to be the beginning of the Russian Empire, as the khanate of Kazan was Muslim and its people, the Tatars, were not Slavic or Finnish, unlike the peoples in the center and north of Muscovy. The Tatars were known for their widespread literacy in Tatar as well as Arabic, which connected them to the larger Muslim world, as well as their sobriety and orderliness. The Danish-French geographer Conrad Malte-Brun stated of the Tatars that, "industrious, sober and generous, the conquered people are superior far to the Russian conquerors" and that "their commercial activity, numerous schools and different institutions place them far above the other inhabitants" (Malte-Brun, 1828: 435-436). From the end of the sixteenth century, Kazan became known as the "gateway to Siberia, as people and supplies were funneled through the town en route to the east, and furs and minerals were brought west. It was made capital of the Volga region in 1708" (Ostrowski, 2004: 733). In that same year, the Kingdom of Kazan was abolished as an administrative division; a revolt broke out against what David J. Matthews and Ravil Bukharaev call "the abolition of the country's name" that was quickly put down but still provided evidence that a sense of difference remained (Historical anthology ..., 2000: 26). Kazan became an important trading center, as well as a center of learning, both for the Russians and for the Tatars, who had their own schools and literature. In 1758 , the Kazan gymnasium, where the Russian poet Gavrila Derzhavin studied, was established. Kazan was often seen as the gateway to Asia and was chosen by the state as the site for the Asiatic Press, founded in 1800, which, as Kazan scholar S. M. Mikhailova notes, "was the only one in the whole of Eastern Russia, in which literature was printed in Arabic, Turkic, Tatar, Persian, Mongolian, Kalmyk, Tibetan, Sanskrit and other languages" (Mikhailova, 1997: 275). The second book printed in Kazan at the press, in 1801, was the seventh part of the Koran, in Arabic, while the entire Koran was published in Arabic in 1803 there 
(Katalog knig ...: 21, 1 [second pagination]). In 1815, the future Slavophile Sergei Aksakov, then a student at Kazan University, bought a copy of the Koran, along with the works of such Russian authors as G. R. Derzhavin, N. M. Karamzin, M. V. Lomonosov, V. A. Zhukhovskii, Prince I. M. Dolgorukov and the Instruction of Catherine the Great, which put forth her liberal ideas in the early part of her reign (Rossiiskaia gosudarstvennaia biblioteka [Russian State Library], f. 3, karton 7, d. 1, 1. 80ob-82). The Koran was first translated into Russian in 1716 and several editions followed (Crews, 2006: 37). The Koran was available for sale in Russian bookstores as well as of interest to young Russian students like Aksakov.

Oriental studies in Kazan were part of the larger Oriental Renaissance in Europe, sparked by the discovery of Sanskrit and the cultural riches of India and the East in the late eighteenth century. The countries of Western Europe were gripped by an intense interest in the languages, art, literature and politics of China, India, Persia and the "East" more generally. In contrast to later, more dismissive, views of the non-West, the era of the Oriental Renaissance was marked by a general belief that the East was the cradle of civilization and the source of light for the world (Schwab, 1984). Russia was ideally placed to take part in this development. As Sergei Uvarov, later the Minister of Education under Nicholas I from 1833-1849, noted in 1810: "Russia lies, so to speak, on Asia... The simplest notions of politics suffice to perceive the advantages that would accrue to Russia were she seriously to occupy herself with Asia. Russia, which has such intimate relations with Turkey, China, Persia, Georgia, would at the same time not only make an immense contribution to the progress of general enlightenment but satisfy its dearest interests as well" (Whittaker, 1978: 514). This would rejuvenate Russian literature and give Russia a new and important role, as "mediatrix between European civilization and Asian wisdom" (ibid: 511). This shows both the similarities and the differences with Western European Orientalism, as the nexus of knowledge and political power Uvarov describes is entirely consistent with Said's vision. However, the idea that Asia would finally put Russia on the map of Europe and that it would mediate between Europe and Asia sets it apart.

Kazan University emerged from a wide-ranging reform of the Russian Empire's university system in 1804 in which new universities were established not only in Kazan but also in Kharkov, Dorpat and Vilna (Flynn, 1988: 40). As James Flynn has noted, the reform embraced the Göttingen model of "a faculty that worked in academic freedom for teachers and learners" (ibid: 8). The 1804 censorship statute, which Charles Ruud terms "the most liberal press law of the imperial period," decentralized censorship control to elected faculty committees in Russia's universities, who were responsible for overseeing publications in their educational districts (Ruud, 1982: 26). The censorship laws were lenient; as Ruud puts it, "the universities were to publish on their own presses whatever they pleased" (ibid: 27). In these favorable conditions, Kazan University became a vibrant center of study not only of the Kazan region but also of the Urals and all of Siberia.

Kazan University was also given responsibility to oversee the massive Kazan Educational District. The School Committee had the responsibility of strengthening existing schools, creating new ones, collecting donations, preparing teachers and the curriculum (Mikhailova, 1991: 141-142). Before 1804, the territory covered by the district had 45 schools with 2304 students and 95 teachers (ibid: 142) By 1825, the district had 10 gymnasia, two main popular schools, 78 district schools, 6621 students and 419 teachers (ibid: 144). Students were not just Russians, but also Tatars, Bashkirs, and Siberian natives such as Tungus and Buriats, among others. In one case, Kazan University professors told the teacher to stop 
instruction in the catechism, as the students were Tatars and Bashkirs, for whom Christianity was alien (ibid: 147, 150). Teachers were encouraged to write descriptions of all or any aspects of the regions in which they taught (ibid: 146-147).

A group of Kazan scholars and professors established the Kazan Society of Lovers of Fatherland Literature in 1806, only two years after the founding of the Kazan University and Educational District. The district served as the means of recruiting members to fill out the membership beyond the five founding members. The first president of the society, Nikolai Ibragimov, in his petition to the director of the Kazan gymnasium, I. F. Iakovkin, emphasized the mutual assistance the members would provide each other in their work on the Russian language. This is striking, given that the original five members were composed of three teachers and two students, yet hierarchical language is absent and the pervasive contemporary commentary on mutual friendly assistance is instead evident. This suggests a voluntary association marked by mutuality. In his request to Iakovkin, Ibragimov wrote: "Desiring to perfect ourselves in the native language, we agreed to exercise it together, in order to mutually assist each others' successes" (Fedotova, 2006: 237). In the 1806 request, Ibragimov stated, "censorship or the critique of works should be by friendly consultation and has nothing in common with satire and ridicule" (ibid). This use of the term censorship was intended literally, as the manuscript proposal for the society's statute reads as follows: "The Society has its own censorship over its own works" (ibid: 241). This was missing from the officially approved text, as were the proposed power to change its own statute and to have an official stamp with the Kazan coat of arms and a rising sun and the motto "It shines on me as well" (Ustav ... , 1815: 16). The society's attempt to take on governmental power within a voluntary association and to extend the mutual assistance model to censorship failed. Only the Free Economic Society (est. 1765), Moscow University, and the Academy of Sciences had the power to censor their own publications at this time (Bradley, 2009: 51). The proposed stamp shows the influence of a regional identity and the Oriental Renaissance's "light from the East".

The secretary of the society, P. S. Kondyrev, asked the Orenburg director of schools to join, among others, in order to take part in the study of not just literature but history and geography and "everything native" (vse otechestvennoe) (Aristov, 1992: 4). Kondyrev set out the scope of the society's activity: "The study of the Russian language and as a result Russian grammar, the interpretation of similar words or synonyms, the meanings of different words, the invention of technical terms, translations and the criticism of the works of classical, medieval and modern authors, the critical analysis of noteworthy compositions, news of such works, of famous authors, information on the history of our and foreign literature in the discussions of literary societies, national and some foreign history, investigations dealing with antiquities and the fine arts, Slavic languages and Slavic literatures in general are the objects of our activity" (Kondyrev, 1815: 44).

For Kondyrev, literature and its study would win Russia a place among the enlightened nations and show the soul of the people. "Love for the language of our fatherland," he wrote, "also sows without fail in our heart an impartial attachment to native mores, the true popular character, which brings about the respect of foreigners, to the belief in one's ancestors, the resolution to be useful to the fatherland, in one word, love for the fatherland" (ibid: 47). This process was not limited to Russia but was found in both the East and the West: "The word is revered as capable of representing the soul of a people; in the works of the Greeks and Romans there is a spirit different from the spirit in the works of other peoples; equally the English, Germans, French, Italians and Eastern peoples can serve as examples" (ibid: 48) 
In true Romantic fashion, the study of language meant not only the collection of linguistic material, but also a voyage into the essence of different nations or peoples. Such knowledge could also be imperial knowledge, as the collection of such material would give the Russian state a deeper insight into the peoples of their empire.

Thus, the idea of Eastern Russia had a very different valence at the height of the Oriental Renaissance than it would have had in the late nineteenth century, when Russification and a narrow view of Russian nationalism were the norm. Despite the many problems of the university and district, the massive scope for research and teaching on the East was exhilarating for those in the faculty who could see the unique role Kazan could play in expanding Europe's knowledge of Asia. In 1815, Kazan University professor P. S. Kondyrev wrote in the Kazan Society's journal: "We live among many non-Russian (inoplemennye) peoples, in the ancient Tatar kingdom, within view of the former ancient Bulgar capital. Tatars, Chuvash, Cheremiss, Mordvins, Zyrians surround us. Armenians, Persians, Bashkirs, Kalmyks, Bukharins and Chinese are closer to us than they are to other societies. We can more conveniently have connections with their language or literature and from this be helpful. How useful it would be to collect the different songs of these peoples, their tales, writings, stories, books, epitaphs... Compiling dictionaries of their languages and conducting philological investigations would also not be useless" (Aristov, 1992: 32). These concerns are quite in line with larger European interests in Eastern languages and customs and thus locate what may have seemed to be the periphery of Kazan at the center of European interests at that time. Certainly no other European university or state had as large a terrain in the East (or anywhere else) to work with.

\section{FROM EASTERN SELVES TO EASTERN LANDSCAPES:}

KAZAN AND EARLY NINETEENTH CENTURY LITERATURE

The East provided inspiration for two generations of Kazan writers in the first two decades of the nineteenth century. For the older generation, the tropes of the East were connected to visions from the era of Catherine the Great of an Eastern persona as both self and other. For the younger generation, the East provided a setting for sentimentalist reflections on the place of the self within a landscape both familiar and exotic. The Kazan Society worked on defining Russianness between East and West.

The Kazan Society was part of a larger movement within educated Russian society that led to the creation of many literary societies in the first two decades of the nineteenth century. Emperor Alexander I (r. 1801-1825) established a more liberal policy toward publishing, allowing for the creation of private printing presses. The Napoleonic Wars encouraged a widespread interest in defining what was Russian as well as questioning the widespread French influence in literature and culture. Literature became the focal point for educated society, as it was able to address issues of Russian nationality by its style and content. The Napoleonic Wars also led to the elite's discovery of the Russian peasant, who played an important role in Napoleon's defeat. Folk themes and folk saying became more prominent in literature. Not for the last time, literature played a key role in defining Russianness.

Kondyrev, the secretary of the Kazan Society, placed it within a larger European framework of voluntary associations: "In all educated states one finds various scholarly Societies, in all capitals of such powers and in the most important scholarly, artistic or trading towns... Such societies greatly assist in the speedy success of sciences, arts, enlightenment, popular education, and even trade, industry and rural economy... Our dear fatherland, 
Russia, has also long had many scientific Societies, in both capitals as well as in Kharkov, Abo, Riga, Vilna and several other towns" (Kondyrev, 1815: 40). The framework for the Kazan Society was thus European civil society, and study of the East was another way of claiming membership in the West and conferring upon Kazan the distinction of being a leading town of the empire.

In the early nineteenth century, literature became the terrain upon which ideas of the purity of the Russian language and, by implication, the Russian people, was debated. In the early nineteenth century, Admiral A. S. Shishkov, a romantic nationalist, as Alexander Martin has noted, argued that "every language developed unique ways of modifying existing words to convey new meanings; in the primary words and the vocabulary subsequently derived from them was stored, he thought, the historical memory of each people's unique spirit and consciousness" (Martin, 1997: 26-27). To this end, he insisted on using only words with Slavonic roots and rooting out all French or other foreign influences. Despite Shishkov's nationalism, he was very much a part of larger European developments, which included other similar projects for pure national languages; his wife was a Russian of German background who remained a Lutheran and spoke French at home with their sons (ibid: 26). In his written work, however, he assailed other nations and languages for sullying the purity of Russian.

The Kazan Society was part of the rejection of Shishkov's purist stance on language. They were among many commentators who saw Russian as part of contemporary European trends; one Moscow reviewer noted that "we want to write sentences and create words in accordance with our own present views, thinking like the French, like the Germans, like all of today's enlightened peoples" (ibid: 36; italics in the original). During this time, then, the Russian language was a fraught subject that connected to issues of Russian history and nationalism. The Kazan Society rejected the extremes of Shishkov's position, arguing that, as the society's founder Nikolai Ibragimov wrote, "by the arrival, migration and merging of different peoples, or by their mutual communal life, when with foreign ideas involuntarily are introduced foreign sayings, from which language becomes more or less mixed; in general a perfectly pure language does not exist" (Ibragimov, 1815a: 120). This pragmatic and tolerant acceptance of mixing was not limited only to language, as we will see.

This interest in the provinces more generally is reflected in its membership, which began in 1806 with only five members, but by 1817 had reached 61 members, 22 of whom, or 36 percent, were from Kazan, while 39, or 64 percent, were from other towns (Aristov, 1992: 4; Spisok ... , 1815: 109-116). Members from Kazan included a broad range of intellectuals, from Kazan University and the Kazan gymnasium, where Ibragimov taught, as well as enlightened clergy, officers serving as honorary inspectors of schools, an army doctor, and a civil servant. One member, a certain Ianuarii Osipovich Iartsov, who received a master's degree in Eastern languages, was listed as "presently resident in Persia" (Spisok ..., 1815: 111). The Kazan Society thus helped to create an arena for intellectual discussions for a cross section of the educated public that was not limited to the gymnasium and university. The members from other towns were spread out across the empire, with many in the area covered by the Kazan Educational District. For example, Ibragimov's former student and future Slavophile patriarch and memoirist Sergei Aksakov was listed at the low rank of collegial secretary and as resident in Buguruslan, a town in Orenburg province (ibid: 112). Other out-of-town members were clearly involved in a variety of provincial voluntary associations. Ivan Sreznevskii, a well-known publicist of the time, was listed as a professor of literature at Kharkhov University and as a member of the Kharkhov Society of Sciences and 
the Society of Lovers of Russian Literature in Yaroslavl (ibid: 113) As with the Kazan members, the out-of-town members included professors, civil servants, and enlightened clergymen. They also included major poets such as Vasilii Zhukovskii, Konstantin Batiushkov, and Petr Viazemskii (ibid: 116).

Sergei Aksakov, one of the earliest members, described the Society as follows: "We met every Saturday to read our compositions and translations in verse and prose. Every member had the right of criticism, and the articles were sometimes corrected on the spot, if the author admitted the justice of the improvements suggested; there was never any quarrelling. If any piece was accepted, it was copied out in a book which we started for the purpose" (Aksakov, 1983: 151). Aksakov emphasized the deep influence Ibragimov had on his writing, both as a young boy and later. In 1810, the society had more than 200 plays and others works and translations and were preparing to publish the first volume of their Works, but Napoleon's invasion of Russia intervened (Aristov, 1992: 14-15). Finally, in 1815, they were able to publish a smaller book, The Celebration of the Society on December 12, 1814, which was Alexander I's birthday (ibid: 16). The society was ready to publish the next volume of its works when the retrograde curator of Kazan University during the Bible Society era, M. L. Magnitskii closed it down, characterizing it as "an empty game of people, gathered in one group not for clear and noble goals, but all for petty vanity" (ibid: 21). Magnitskii rejected the secular nature of the society, as he wished to introduce a rigid code of Christian behavior at the university that was quite at odds with earlier classical and Catherinian norms.

One of the founding members of the Kazan Society who we have already met was Nigmat (Nikolai) Misailovich Ibragimov, who, from 1802 in the Kazan gymnasium, taught Slavonic grammar to future Slavophile Sergei Timofeevich Aksakov, using Ibragimov's own textbook. In his memoirs, Aksakov wrote that Ibragimov "taught Russian literature and mathematics in the same form. His surname and his appearance alike clearly betrayed his Tatar or Bashkir origins; his head was large, his eyes small and piercing, with a very pleasant expression; he had prominent cheekbones and a huge mouth. This man had a great influence on my literary development, and his memory is dear to me. He first encouraged me and gave me what I may call a push in the right direction" (Aksakov, 1983: 84-85). In 1806, Ibragimov founded the Kazan Society of Lovers of Fatherland Literature, in which Aksakov and others presented their original works for evaluation. In addition, Ibragimov wrote several Russian folk songs, one of which, In a Field a Birch Tree Stood, has enjoyed widespread popularity to the present day (Aristov, 1985: 45-55). His poetry presented the East as both self and other. For Ibragimov, who was Tatar, this acquired a special valence. Despite his publications, he was passed over for a position at Kazan University in favor of his Russian protégé, Kondyrev, suggesting that his Tatar origin hindered his promotion.

Ibragimov's poem, Verses on the Joyous Birthday of the Kirgiz-Kaisak Tsarevitch $K$ Khor, read at the December 12, 1814 meeting, combined the themes of Catherine the Great's and Alexander I's rule and imagined the east as the heart of the empire. Catherine's scenario of rule had emphasized the love of her subjects for their empress, including the many different peoples of the empire. The "vision of a vast multinational empire became especially important to Catherine's image as her reign progressed... By the end of Catherine's reign, it was important to confirm that Russia was not only an empire, but the most imperial of nations, comprising more peoples than any other" (Wortman, 1995: 136). In contrast, Alexander I's scenario of rule emphasized the West in its classicism and Enlightenment. The Napoleonic Wars only heightened this Western orientation, as Alexander came 
to see himself as the savior of Europe. The East, which had been an important part of Catherine's presentation of self and reign, as she had overseen territorial expansion in the Black Sea region, was relegated to the periphery in Alexander's. Ibragimov sought to change this by drawing on Catherinian tropes of the East.

In order to understand Ibragimov's poem, we need to look at its predecessors in the writing of Catherine the Great and Gavrila Derzhavin. Catherine's works introduced an Eastern identity as a playful persona for the empress and her favored grandson, the future Alexander I. Catherine's story, The Tale of the Crown Prince Kblor, which she wrote in 1781, tells of the kidnapping of Khlor (Alexander) by the Kirgiz-Kaisak Khan and his encounter there with Felitsa, the daughter of the khan, who offers him good advice, a sense of right and wrong, and her son, Rassudok (Reason), to be Khlor's guide. Khlor, with the assistance of Reason, is able to find the rose without thorns, a symbol of virtue and return to his kingdom triumphant. In the tale, Catherine's choice of the "'Kirgiz princess,' also represented her imperial self, a ruler of exotic oriental lands" (ibid: 143). "Kirgiz-Kaisak" was the term the Russians used to refer to the nomadic, Muslim Kazakhs. Kirgiz more broadly referred to all nomadic peoples of the steppe (Brower, 1997: 128-129; Knight, 2000: 83). The tale became an important part of Alexander's upbringing, and Catherine even built a temple of the rose for Alexander at the imperial palace of Tsarskoe Selo. The temple included a ceiling with Peter the Great looking down on a prosperous Russia leaning on a shield with a picture of Felitsa/Catherine (Wortman, 1995: 159).

The tale displays a mingling of East and West. As Harsha Ram notes, Khlor becomes princely only after being kidnapped and absorbing his captors' Eastern culture. "The Turkic peoples remain an alien and threatening force in both stories," Ram writes, "yet have <...> a capacity to impart moral values, which, in the true tradition of the Enlightenment, are assumed to be universal. Hence the peculiar compromise, $\langle\ldots\rangle$ between territorial aggression and cultural tolerance, which was also to be Catherine's standard response to the subject peoples of her empire" (Ram, 2006: 106). This was but one of many iterations of the imperial scenario of power, which, until the late nineteenth century, as Richard Wortman has noted, represented the Romanovs as foreigners. An Eastern persona united both the idea of the ruling house as foreign with a reminder of the vastness of the Russian Empire, creating an internal royal foreigner. This is particularly interesting given that since the foundation of Kiev, rulers of what would become the Russian Empire had focused on their origins from the west or north, not the east (Wortman, 1995). In addition, Catherine's status as a German princess meant that some Russian courtiers were cool to her when she first arrived, so an Eastern persona would partly make up for her all-too-Western self.

Gavrila Derzhavin, one of eighteenth century Russia's major poets, gained fame with his poem Felitsa, which identified Catherine as the khan's daughter Felitsa and himself as a Tatar murza (an allusion to murza Lentyag (Lazybones), a minor character in Catherine's tale). The full title of Felitsa is worth mentioning, as it shows Derzhavin's use of Eastern tropes: "Ode to the Wise Kirgiz-Kaisak tsaritsa Felitsa, written by a Tatar murza [noble], long resident in Moscow, but living due to his business in St. Petersburg. Translated from the Arabic in 1782" (Derzhavin, 1957: 374). Derzhavin himself claimed "noble Tatar ancestry" and was "an active participant in quelling the Pugachev Revolt, and the owner of several villages in the Orenburg district bordering the Kyrgyz horde over which Felitsa's father was said to have ruled" (Ram, 2006: 115). The poem delighted Catherine so much that she sent Derzhavin a package inscribed "From Orenburg from the Kirgiz princess to Mirza Derzhavin". Inside was a "gold snuffbox encrusted with diamonds" and five hundred gold pieces 
(Khodasevich, 2007: 96). The poem consisted of the Murza asking Felitsa for advice on how to live and places her within the imperial geographical tradition of glorying in the vast expanse of the empire:

Place her throne on the hills of Scandinavia,

Kamchatka and the Golden Hills,

From the countries of Timur to the Kuban

(Ram, 2006: 113-114).

The character of the Murza (the Tatar word for noble) provided an Eastern mask for Derzhavin that was both self and Other. Derzhavin characterizes his poem cycle to Felitsa as his Tatar songs sung to praise the empress (ibid: 111). "Both the artist and the non-Russian subject (and let us remember that the Murza is botb a poet and a Tatar) submit voluntarily to Felitsa's sovereignty" (ibid: 112). Derzhavin's Murza is also a reflection of larger social processes, as Catherine had decided to incorporate the Tatar nobles and Muslim clergy more closely into the imperial system in order to shore up the Volga region as part of her ambitious southern policy, which involved plans for Russian dominance of the Black Sea and retaking of Istanbul (Ram, 2006: 115). Increased tolerance toward Islam within the empire was part of this vision, partly due to the influence of Enlightenment ideas and partly due to practical considerations of order. The Murza places Catherine's rule within the boundaries of the fabled East when he asks:

But where does your throne shine in the world?

Where do you flourish, celestial branch?

In Baghdad, Smyrna, Kashmir?

He further states that "I pray the great prophet that I may touch the dust of your feet, that I may enjoy the sweet stream of your words and your look" (Wiener, 1902: 390). Catherine is reimagined as an eastern luminary, bringing light both to and from the East as well as to the Murza. However, this is seen as a future event, while Ibragimov's East, as we will see, had already been enlightened.

In Ibragimov's poem, Verses on the Joyous Birthday of the Kirgiz-Kaisak Tsarevitch Khlor, read at the December 12, 1814 meeting of the Kazan Society, which was the birthday of Alexander I, who he refers to as Khlor. The very title suggests the hybrid nature of East and West, as it refers to Khlor as the "Kirgiz-Kaisak tsarevitch". In Catherine the Great's tale, the two were kept firmly apart, with the tsarevitch referring to his place of origin and return, presumably in Russia, while the Kazakh provide but an Eastern interlude. Ibragimov's reformulation places Khlor / Alexander I firmly within the East. The first stanza also firmly appropriates Khlor into an Eastern genealogy:

Foster child and beloved grandson

Of the God-like Felitsa,

Oh Khlor, turn your ear to the new sound

Of the Kirgiz Kaisak pipe.

(Ibragimov, 1815b: 70)

Here, there is some slippage between the well-known self-identification of Catherine the Great as Felitsa with the status of Felitsa in the poem as the daughter of the khan. This same duality is found in the characterization of Khlor as both foster child and grandson. The East here is both strange and familial.

In addition, Ibragimov compares his poetry to Kazakh pipes and, implicitly, himself to a Kazakh piper and a part of this nomadic, Muslim people of Central Asia. This would have made sense to his listeners, as Tatars like Ibragimov were the intermediaries of the Russian 
state to the steppe nomads. As Andreas Kappeler notes, "in the cultural and economic spheres the Russian government, from the end of the eighteenth century onwards, initially employed Kazan Tatars in order to 'civilize' the Kazakhs” (Kappeler, 2001: 189). The Tatars spread Islam and education and even official orders were transmitted to the steppe nomads using Tatar, which was written in Arabic, not Cyrillic, script. As one scholar notes: "The state had no intention of creating a joint Muslim cultural sphere on its border. But this was the inevitable outcome of the way in which the Tatars interpreted their mission as 'imperial civilizing agents"” (Kosach, 1998: 58). Thus, while Derzhavin, a Russian with a nominally Tatar background, took on the mask of the Tatar noble, Ibragimov, a Tatar, took on the mask of a Kazakh piper in his role as a Tatar-Russian enlightener. Note, too, that the pipes have a "new sound," perhaps because the song itself is in Russian, not Tatar or Kazakh.

Ibragimov reimagines all of the Russian Empire as an alliance between North and East against the forces of the South and West, who, we will see, were unable to stop the advance of Napoleon. The Russians are presented as eastern hordes and are said to have seen the light and prayed to the Prophet thirty seven years prior, when the future Alexander I was born.

Thus thirty seven years have passed,

Since the hordes of the North East

With Your birth saw the light

And prayed for you to the Prophet.

The term horde (ord) refers to descendants of the Golden Horde and to the Mongols in general. A more subversive reading might argue that since the Muslims recognize Jesus as a prophet, this may refer to prayer to Jesus rather than to Muhammad.

Ibragimov places himself on the periphery: "We live here far away, in the backwoods / Happy under Your dominion". This claim merely serves to highlight the enlightening role of Alexander I, which is emphasized far more than his military successes:

However, since You have provided
Everywhere a path to reason and taste,
So we don't only consult the Koran,
But we weave verses in the ulus. ${ }^{4}$
But in the camp of the Golden Horde
There is a temple to the Muses raised by You,
Where the youth zealously work to grasp
The cryptographic syllables of learning.

(Ibragimov, 1815b: 71)

This is an East where science and Enlightenment have entered the camp ( $v$ stane - the root also used for Afghanistan, etc.) of the peoples of the East. The claim is not that the Koran is no longer read, but that it is not the only book read. The Tatars had a long history of education, literacy, and writing that went beyond religious exegesis, so placing Alexander I at the source of this overstated. In 1810, Kondyrev and the curator of the Kazan Educational District proposed to open an Eastern School in the madrasa of Kazan, to which the Orenburg mufti, or Muslim religious administration, agreed to raise money for a building and other expenses from the Muslim population (Mazitova, 1972: 108). In 1819 Kondyrev proposed the creation of a Tatar high school that would provide a "synthesis of 'Muslim and European scholarship"” (Petr Sergeevich Kondyrev, 2002: 265).

The role of the narrator is far less prominent in Ibragimov's poem than in Derzhavin's. While Derzhavin's narrator spent a considerable amount of time listing his faults in order to 
heighten the pathos of his request for enlightenment, Ibragimov's narrator is far more selfeffacing, comparing himself to Derzhavin in the following:

The Tatar Murza has described

This day with a plume worthy of glory, And shown as if on the palm of one's hand The felicity of Your dominion.

He clearly saw ahead,

While I am blinded by the present;

But Khlor! At least in this come descend:

I am equal with him in love for You.

(Ibragimov, 1815b: 71)

Derzhavin is portrayed as a visionary prophet, while Ibragimov presents himself as a blind singer capable of deep emotion, placing the poem within the proto-Romantic discourse on emotion prevalent at the time. Left unstated but quite evident to the listeners and viewers would have been the common Tatar heritage of Derzhavin and Ibragimov. The narrator did not so much display his Tatar identity as he embodied it. The East was also deployed as the place that, under the just rule of Alexander I, defeated Napoleon when the West was powerless: "He who was a terror to the South and West, / Here became the laughing stock of the universe" (Ibragimov, 1815b: 73). This reinserts the East into the discourse of the Napoleonic Wars, which had shifted the focus to the west.

Overall, Ibragimov's poem reinvented the Eastern tropes of Catherine's era in order to make the East relevant for the new age of Alexander. The East, which had become peripheral to discussion of the Russian Empire under Alexander, was once again placed in the center with the identification of Alexander as both an angel, which was a very common trope, and as the Kazakh tsarevich Khlor, which brought together East and West into a hybrid being that was able to defeat Napoleon where Western Europe could not. Ibragimov takes on multiple Eastern selves here, as Tatar singer and as Kazakh piper, to provide a chorus of praise for the tsar. Despite the protestations of the narrator that he lives in the periphery, his poem seeks to reorient the empire to the east.

The younger generation represented by Ibragimov's students provide a different view of the East. Rather than a sense of self, the East provided a landscape for sentimental reflections and projections. The East, including such key architectural symbols as the ruined capital of Bulgar, destroyed by the Mongols in 1236, was described as Gothic, collapsing East and West. This shows the increased influence of sentimentalist and proto-Romantic trends among the younger generation. Bulgar was a symbol of great importance to Tatars, as it was the forerunner of the Kazan Khanate. At present, Bulgar is seen as the origin point of the Tatar people, particularly by those who wish to emphasize the purity of the Tatars as separate from the Mongols. One scholar has argued, however, that a synthesis of the Tatars from Bulgar and the invading Mongols is a more likely scenario (Rorlich, 1986: 5). Bulgar has been a major trope in Tatar poetry from at least the fourteenth century Poem of Edighey, which lamented the destruction of Bulgar by Timur and the subsequent invasion "By the red-faced Russian Prince, whose busy beard / Concealed his mouth... / He came to plunder like a highway-robber, / And smashed the holy city of Bolgar" (Historical anthology ..., 2000: 50). Such a negative view would not likely be espoused by Russians, but we will see that the connection of Bulgar with sad reflections remained.

Sentimentalism rejected the Old Style emphasis found in Shishkov's works, as did the older generation in the Kazan Society. As Alexander Martin has put it, "in contrast to the 
emphasis of Lomonosov, Sumarokov, and other earlier writers whom Shishkov admired on grand themes and genres, sentimentalism encouraged the examination of private emotions through poems and short stories that were deliberately unpretentious in both length and style" (Martin, 1997: 29-30). The leading sentimentalist of the era, Nikolai Karamzin, had a tremendous influence both due to his literary style, which aimed at imitating French rather than Church Slavonic, and to his subjects, which involved the examination of emotional upheavals, such as in his most famous story, Poor Liza, which tells of a seduced and abandoned peasant girl that was innovative in its belief that peasants had emotions and in its believable Russian setting. How would visions of the East fit into this self-consciously Western model?

In the manuscript journals The Arcadian Shepherds and The Journal of Our Exercises, Sergei Aksakov and the Panaev brothers, Aleksandr, Nikolai and Ivan, tried out their poetry and prose. In a series of prose pieces, Aleksandr Panaev wrote a series of descriptions of areas around Kazan that dealt with Eastern themes (Kazanskii universitet ... , 2002: 390). From 1805 Panaev was a student in Kazan University and in 1806 became one of the first members of the Kazan Society. As a student, his main interest was in natural history, which led him to collect butterflies with Aksakov. During the Napoleonic Wars he served in the army, retiring in 1820. During the 1820s he published several poems in the journal The WellIntentioned, but seems to have not been active as an author from then until his death in 1868 (ibid).

In Panaev's unpublished article, My Walk in the Town of $T^{*}$, which most likely describes the town of Tetiushy, where his family lived, he described his vacation at home, where he visited for several days with his mother and other relatives before setting off on a short sentimental journey along the Volga, where climbed a hill and saw from a distance the ruins of Bulgar:

climbing up its stony slopes, and - although everyplace was surrounded by precipices I finally reached their very peak, where seated on a mossy stone I looked far along the left bank of the Volga, at the ruins of the ancient Bulgar capital. Then and now exist two great columns, from which the ancient imams loudly proclaimed the name allab, calling Muslims to prayer. Long did I marvel at these Gothic remains of the famous realm and thought of the decay of all sublunar things. Then I went down the hill and walked through meadows dotted with flowers (Otdel rukopisei, Rossiiskaia gosudarstvennaia biblioteka [OR RGB; Department of Manuscripts, Russian State Library], f. 3, karton 5, d. 1, 1. 8).

Another trip, also to Bulgar, was given a far more virile frame, one that emphasized the independence and masculinity of the author:

Living so close to Bulgar, from such a memorable place in Russia, - to live and not visit there, would be unpardonable. I am very inquisitive, and always look on things of this sort with pleasure. It was left only to cross the Volga, travel 15 versts, and then to satisfy my desire completely. I was unable to restrain myself from saddling a horse, saying goodbye and, having swum the turbulent element, to gallop along the wide road to Bulgar (OR RGB, 1. 101-101ob).

Later in the work he would emphasize the Gothic elements of Bulgar and draw upon the tradition of the imperial sublime analyzed by Harsha Ram, which emphasized the vertiginous experience of the expanse and power of the Russian Empire when the author identified with it (Ram, 2006). As Panaev wrote, "But finally I reached the goal of my desire. - I saw 
Bulgar - I saw from afar this great Gothic structure, by which every passerby is struck with amazement. I saw and spurred on my horse and in a minute was already alongside one of the minarets... I looked on it for a long time and was amazed and my curiosity grew from hour to hour. I wanted to be on the very top of this pillar, - from there I wanted to measure with my eyes the horizon, wanted to see the Volga and its surroundings; in one word I wanted to be there, where it was rough and difficult to ascend" (OR RBG, 1. 101ob-102). Here, the East provokes a desire for mastery and control. Characterizing the ruins of Bulgar as Gothic assimilates them into European proto-Romanticism and draws a parallel between the Tatars and the pagan Germanic tribes of the Goths, some of whom migrated in the fourth century to the Crimea, on the Black Sea, later the site of the Khanate of Crimea. As late as the mideighteenth century, scholars found some traces of Gothic words from residents of the Crimea (Bradley, 1899: 363-364; Kozelsky, 2009: 105; Robinson, 1992: 50-51). Of course, the Romantic idea of Gothic architecture as wild and exhilarating is not absent. The ascent of the tower, although described as "terrifying" and requiring the clambering over of difficult patches, leads to victory: "Finally, however, I succeeded in overcoming all dangers and in a moment found myself on the upper platform!" (OR RBG, 1. 102ob).

There, Panaev was given a view of the entire region, including the town from which, in the companion piece, he had viewed Bulgar: "From one side in the distance flowed the great Volga along the spine of which were visible ships with unfurled sails. The right bank of the river was bounded in its flowing by mountains, on the slopes of which in a pleasant valley Tetiushy with its yellow church was visible" (OR RGB, 1. 103). This emphasized the present Christianity of the landscape, while Islam was cast as something from the remote past when describing the towers of Bulgar: "These elevated places served at some time for Muslims from which the heralds of prayer raised them in the mosques $<\ldots . .>$ In icy melancholy silence long I marveled at this amazing ancient building!" (OR RGB, 1. 104). The call to prayer had been replaced with complete silence. One would not guess at the vibrant role Tatars continued to play in Kazan from the description. Panaev then reflects on the destructive powers of time: "I surrounded myself with mournful ideas and washed with my sight the traces of angry and uncaring time from objects. What can stand against his sharp all destroying scythe?" (OR RGB, 1. 104-104ob).

In conclusion, Ibragimov's work provides a clear example of East as both self and Other. He mixes East and West so that Khlor (Alexander) represents both at once and is related to both. In this way, the victory over Napoleon can be presented as a victory of the East over the West. Ibragimov goes further than Catherine or Derzhavin to suggest that the mixture itself was key for Russian history. This celebration of mixture was different from much of Western European Orientalism. Panaev, in contrast, presents a more usual Orientalist discourse of the East and Islam whose greatness is entirely in the past. However, even here the East is within sight of home, allowing once more for a mixture of the strange and the familial.

\section{NOTES}

${ }^{1}$ Adeeb Khalid has challenged Knight's argument that Russian Orientalism was less focused on superiority by thinking through the Russian conquest of Central Asia in the late nineteenth century (Khalid, 1998, 2000). However, it is important to note that Russian attitudes towards the East and to race changed in the 1860s and especially by the 1880s, becoming more racist and imperialist and thus converging, in a negative way, with the Western European model of the new imperialism.

2 A similar rejection of Islam in Central Asia is detailed in: Becker, 1986. But see: Crews, 2006.

${ }^{3}$ Unless noted otherwise, all translations from Russian are by the author.

${ }^{4}$ Nomad camps and kinship groups. 


\section{REFERENCES}

Aksakov, S. (1983) A Russian schoolboy. Oxford ; New York, Oxford University Press. xi, 161 p.

Andreeva, E. (2007) Russia and Iran in the great game: Travelogues and Orientalism. London, New York, Routledge. xii, 273 p.

Aristov, V.V. (1985) Kazanskie nakbodki: Poiski literaturnye i istoricheskie [Kazan finds: Literary and historical searches]. Kazan, Tatarskoe knizhnoe izdatel'stvo [Tatar Publishing House]. 192 p. (In Russ.).

Aristov, V. V. (1987) Stranitsy slavnoi istorii: rasskazy o Kazanskom universitete [Pages of a glorious history: Stories of Kazan University]. Kazan, Kazan University Publ. 222 p. (In Russ.).

Aristov, V. V. (1992) Pervoe literaturnoe obshchestvo povolzb'ia (K istorii Kazanskogo obshchestva liubitelei otechestvennoi slovesnostiv 1808-1818 gg.) [The first literary society in the Volga regions (Toward the history of the Kazan Society of Lovers of Fatherland Literature in 1808-1818]. Kazan, Kazan University Publ. 45 p. (In Russ.).

Bassin, M. (1999) Imperial visions: Nationalist imagination and geographical expansion in the Russian Far East, 1840-1865. Cambridge ; New York, Cambridge University Press. xiv, 329 p.

Becker, S. (1986) The Muslim East in nineteenth century Russian popular historiography. Central Asian Survey, vol. 5, no. $3 / 4$, pp. $25-47$.

Bradley, H. (1899) The Goths, from the earliest times to the end of the Gotbic dominion in Spain. New York, G. P. Putnam's Sons. 376 p.

Bradley, J. (2009) Voluntary associations in tsarist Russia: Science, patriotism, and civil society. Cambridge, MA : Harvard University Press. 366 p.

Brower, D. (1997) Islam and ethnicity: Russian colonial policy in Turkestan. In: Russia's Orient: Imperial borderlands and peoples, 1700-1917 / ed. by D. R. Brower and E. J. Lazzerini. Bloomington, IN, Indiana University Press. 339 p. Pp. 115-135.

Bulich, N. N. (1887) Iz pervykb let Kazanskogo universiteta (1805-1819) [From the first years of Kazan University (1805-1819)] : [in 2 pts.]. Kazan, Tipografiia Imperatorskogo Universiteta [Printing House of the Imperial University]. Pt. 1. 639 p. (In Russ.).

Crews, R. (2006) For prophet and tsar: Islam and empire in Russia and Central Asia. Cambridge, Harvard University Press. $463 \mathrm{p}$. Russ.).

Derzhavin, G. R. (1957) Stikhotvoreniia [Poetry]. Leningrad, Sovetskii Pisatel' Publ. 468 p. (In

Druzhinina, I. A. (2006) Izuchenie anticbnosti $v$ Kazanskom universitete, XIX - 20-e gody $X X$ veka [The study of antiquity at Kazan University, 19th century - 1920s]. Kazan, Kazan University Publ. 156 p. (In Russ.).

Fedotova, O. (2006) «Zhelaia usovershenstvovat' sebia v otechestvennoi slovesnosti...» ["Desiring to perfect ourselves in our native tongue...”]. Ekbo vekov, no. 2 (45), pp. 237-241. (In Russ.).

Flynn, J. T. (1988) The University reform of tsar Alexander I, 1802-1835. Washington, DC, Catholic University of America Press. 283 p.

Garzavina, A. V. (1987) «V Kazan', professoru K. F. Fuksu...» [“To Kazan, to Professor K. F. Fuchs]. Kazan, Tatarskoe knizhnoe izdatel'stvo [Tatar Publishing House]. 239 p. (In Russ.).

Garzavina, A. V. and Novitskii, A. I. (1984) Moia Kazan': istoricheskii i arkbitekturno-kbudozhestvennyi oblik [My Kazan: Historical and architectural-artistic aspects]. Kazan, Tatarskoe knizhnoe izdatel'stvo [Tatar Publishing House]. 191 p. (In Russ.).

Geraci, R. P. (2001) Window on the East: National and imperial identities in late tsarist Russia. Ithaca, NY, Cornell University Press. 389 p.

Hagen, M. von (2007) Federalisms and pan-movements: Re-imagining Empire. In: Russian empire: Space, people, power, 1700-1930 / ed. byJ. Burbank, M. von Hagen, and A. Remnev. Bloomington ; Indianapolis, IN, Indiana University Press. 538 p. Pp. 494-510.

Historical anthology of Kazan Tatar verse: Voices of eternity (2000) / ed. and transl. by D. J. Matthews and R. Bukharaev. Richmond, England, Curzon. 209 p.

Ibragimov, N. (1815a) O mnogoznamenatel'nosti i obshchem izmenenii slov [On multiplicity and the general changes of words]. In: Torzhestvo obshchestva Dekabria 12 dnia 1814 goda [The celebra- 
tion of the society on December 12, 1814]. Kazan, V Universitetskoi tipografii [At University Printing House]. 436 p. Pp. 120-129. (In Russ.).

Ibragimov, N. (1815b) Stikhi na vseradostnyi den' rozhdeniia Kyrgyz-kaisatskogo tsarevicha Khlora [Verses on the joyous birthday of the Kirgiz-Kaisak Tsarevich Khlor]. In: Torzhestvo obshchestva Dekabria 12 dnia 1814 goda [The celebration of the society on December 12, 1814]. Kazan, V Universitetskoi tipografii [At University Printing House]. 436 p. (In Russ.).

Kappeler, A. (2001) The Russian empire: A multietbnic bistory. Harlow, Longman. xxiii, 455 p.

Katalog knig, otpechatannykb v tipografii Imperatorskogo Kazanskogo universiteta s 1800 po 1896 god [Catalogue of books published at the press of the Imperial Kazan University from 1800 to 1896]. S.l., s.a. (In Russ.).

Kazanskii universitet, 1804-2004: Biobibliograficheskii slovar' [Kazan University, 1804-2004: Biobibliographical Dictionary] (2002) : in 3 vols. / ed. by G. N. Vulfson et al. Kazan, Kazan University Publ. (In Russ.).

Khalid, A. (1998) The politics of Muslim cultural reform: Jadidism in Central Asia. Berkeley, CA, University of California Press. 335 p.

Khalid, A. (2000) Russian history and the debate over Orientalism. Kritika: Explorations in Russian and Eurasian History, vol. 1, no. 4 (Fall), pp. 691-699. DOI: 10.1353/kri.2008.0032

Khodasevich, V. (2007) Derzbavin: A biograpby / transl. and introd. by A. Brintlinger. Madison, WI, University of Wisconsin Press. $281 \mathrm{p}$.

Knight, N. (2000) Grigor'ev in Orenburg, 1851-1862: Russian Orientalism in the service of empire? Slavic Review, vol. 59, no. 1 (Spring), pp. 74-100. DOI: 10.2307/2696905

Kondyrev, P. (1815) Istoricheskoe obozrenie obshchestva i o pol'ze onogo [Historical overview of the society and on its usefulness]. In: Torzhestvo obshchestva Dekabria 12 dnia 1814 goda [The celebration of the society on December 12, 1814]. Kazan, V Universitetskoi tipografii [At University Printing House]. 436 p. (In Russ.).

Kosach, G. G. (1998) A Russian city between two continents: The Tatars of Orenburg and state power. In: Russia at a crossroads: History, memory and political practice / ed. by N. Schleifman. London ; Portland, OR, Frank Cass. 235 p. Pp. 33-88.

Kozelsky, M. (2009) Christianizing Crimea: Shaping sacred space in the Russian empire and beyond. DeKalb, IL, Northern Illinois University Press. 270 p.

Layton, S. (1994) Russian literature and empire: Conquest of the Caucasus from Pushkin to Tolstoy. Cambridge ; New York, Cambridge University Press. xi, 354 p.

Layton, S. (1997) Nineteenth-century Russian mythologies of Caucasian savagery. In: Russia's Orient: Imperial borderlands and peoples, 1700-1917 / ed. by D. R. Brower and E. J. Lazzerini. Bloomington, IN, Indiana University Press. 339 p. Pp. 80-99.

Malte-Brun, M. [Malte-Brun, C.] (1828) Universal geograpby, or A description of all parts of the world, on a new plan, according to the great natural divisions of the globe; accompanied with analytical, synoptical, and elementary tables: [in 8 vols.]. Boston : Wells and Lilly. Vol. VI. $700 \mathrm{p}$.

Martin, A. M. (1997) Romantics, reformers, reactionaries: Russian conservative thought and politics in the reign of Alexander I. DeKalb, IL, Northern Illinois University Press. x, $294 \mathrm{p}$.

Mazitova, N. A. (1972) Izuchenie blizhnego $i$ srednego vostoka $v$ Kazanskom universitete (pervaia polovina XIX veka) [The study of the Near and Middle East in Kazan University (The first half of the 19th century)]. Kazan, Kazan University Publ. 225 p. (In Russ.).

Mikhailova, S. M. (1979) Kazanskii universitet $i$ prosveshchenie narodov Povolzb' $i$ i $i$ Priural' ia (XIX vek) [Kazan University and the education of the peoples of the Volga and Urals regions in the 19 th century]. Kazan, Kazan University Publ. 224 p. (In Russ.).

Mikhailova, S. M. (1991) Kazanskii universitet $v$ dukbovnoi kul'ture narodov vostoka Rossii $(X I X v$.) [Kazan University in the spiritual culture of the peoples of the east of Russia in the 19th century]. Kazan, Kazan University Publ. 359, [1] p. (In Russ.).

Mikhailova, S. M. (1997) Razvitie orientalistiki v Kazanskom universitete v XIX veke [The development of Oriental studies at Kazan University in the 19th century]. In: Kazan', Moskva, Peter- 
burg: Rossiiskaia imperiia vzgliadom iz raznykb uglov [Kazan, Moscow, St. Petersburg: Multiple faces of the Russian empire]/ ed. by B. Gasparov et al.]. Moscow, OGI Publ. 414 p. Pp. 275-301. (In Russ.).

Mikhailova, S. M. and Korshunova, O. N. (2006) Kazanskii universitet: mezhdu Vostokom i Zapadom [Kazan University between East and West]. Kazan, Kazan State University Publ. 207 p. (In Russ.).

Mohrenschildt, D. von (1981) Toward a United States of Russia: Plans and projects of federal reconstruction of Russia in the nineteenth century Rutherford, NJ, Fairleigh Dickinson University Press. 309 p.

Ostrowski, D. (2004) Kazan. In: Encyclopedia of Russian History : in 4 vols. / editor-in-chief J. R. Millar. New York : Macmillan Reference. Vol. 2: E-L. 425-882, [4] p.

Petr Sergeevich Kondyrev. (2002) In: Glukhov-Nogaibek, M. Kazanskii retro-leksikon [Kazan old-fashioned lexicon]. Kazan, Osnova Publ. Center. 575 p. (In Russ.).

Ram, H. (2006) The imperial sublime: A Russian poetics of empire. Madison, WI, University of Wisconsin Press. 307 p.

Robinson, O. W. (1992) Old English and its closest relatives: A survey of the earliest Germanic languages. Stanford, CA, Stanford University Press. 290 p.

Rorlich, A.-A. (1986) The Volga Tatars: A profile in national resilience. Stanford, Hoover Institution Press, Stanford University. 288 p.

Ruud, C. A. (1982) Fighting words: Imperial censorship and the Russian press, 1804-1906. Toronto, University of Toronto Press. 327 p.

Said, E. (1979) Orientalism. New York, Vintage Books. 368 p.

Schimmelpenninck van der Oye, D. (2004) Mirza Kazem-Bek i Kazanskaia shkola vostokovedeniia [Mirza Kazem-Bek and the Kazan School of Oriental Studies]. In: Novaia imperskaia istoriia postsovetskogo prostranstva [A new imperial history of the post-Soviet space]/ ed. and comp. by I. Gerasimov et al. Kazan, Tsentr issledovanii natsionalizma i imperii [Center for the Study of Nationalism and Empire]. 656 p. Pp. 243-270. (In Russ.).

Schwab, R. (1984) The Oriental Renaissance: Europe's rediscovery of India and the East, 1680-1880. New York, Columbia University Press. 542 p.

Smith-Peter, S. (2004) How to write a region: Local and regional historiography. Kritika: Explorations in Russian and Eurasian History, vol. 5, no. 3 (Summer), pp. 527-542. DOI: 10.1353/ kri.2004.0046

Spisok chlenov Obshchestva v nachale 1817 goda [List of members of the Society in early 1817]. (1815) In: Torzhestvo obshchestva Dekabria 12 dnia 1814 goda. Kazan, Univ. tip. 436 p. (In Russ.).

Ustav Kazanskogo Obshchestva Liubitelei otechestvennoi Slovesnosti [The Charter of Kazan Society of Lovers of Fatherland Literature]. In: Torzhestvo obshchestva Dekabria 12 dnia 1814 goda [The celebration of the society on December 12, 1814]. Kazan, V Universitetskoi tipografii [At University Printing House]. 436 p. (In Russ.).

Vishlenkova, E. A. (2003) Kazanskii universitet aleksandrovskoi epokbi [Kazan University of the Alexander era]. Kazan, Kazan University Publ. 240 p. (In Russ.).

Whittaker, C. (1978) The impact of the Oriental Renaissance in Russia: The case of Sergej Uvarov. Jabrbücher für Geschichte Osteuropas, vol. 26, no. 4, pp. 503-524.

Wiener, L. (1902) Anthology of Russian literature from the earliest period to the present time. New York, G. P. Putnam's Sons. 523 p.

Wolff, L. (1994) Inventing Eastern Europe: The map of civilization on the mind of the Enlightenment. Stanford, Stanford University Press. 419 p.

Wortman, R. (1995) Scenarios of power: Myth and ceremony in Russian Monarcby : in 2 vols. Princeton, NJ, Princeton University Press. Vol. 1: From Peter the Great to the death of Nicholas I. $469 \mathrm{p}$.

Zagoskin, N. P. (1902) Istoriia Imperatorskogo Kazanskogo universiteta za pervye sto let ego sushchestvovaniia 1804-1904 [The history of the Imperial Kazan University for the first hundred years of its existence, 1804-1904]. Kazan, Tipolitografiia Imperatorskogo Kazanskago universiteta 
[Typolithography of the Imperial Kazan University]. Vol. 2. Pt. 2: 1814-1819. 698, XVIII, VII p. (In Russ.).

Submission date: 16.01.2016.

\author{
ПРОСВЕЩЕНИЕ С ВОСТОКА: КАЗАНСКИЙ УНИВЕРСИТЕТ \\ И РОССИЙСКИЕ КОНЦЕПЦИИ ВОСТОКА В НАЧААЕ ХІХ ВЕКА \\ С. СМИт-ПИТЕР \\ (ГОРОДСКОЙ УНИВЕРСИТЕТ НЬЮ-ЙОРКА, США)
}

В статье прослежено, как ряд авторов в первые годы существования Казанского университета (осн. в 1804 г.) рассматривали Восток одновременно как себя и Аругого. Ренессанс ориенталистики в этот период видел в Востоке источник знания и света. Это объясняет преобладание более позитивного взгляда на Восток, чем в конце XIX в., когда в Россию из Европы проникла имперская враждебность к Востоку.

Старшее поколение казанских авторов 1810-х годов испытало влияние екатерининского классицизма и переняло его тропы, вновь сделав Восток центром российских дел и воспевая соединение Востока и Запада. На младшее поколение большее влияние оказал сентиментализм. Оно считало Восток близким себе, но все же отдельным от себя.

Изучая этих авторов, мы глубже понимаем, как Россия и Восток взаимосвязаны на институциональном, интеллектуальном и личностном уровнях.

Ключевые слова: ориентализм; Россия между Востоком и Западом; Казанский университет; русская литература; Сергей Аксаков; татары

\title{
СПИСОК АИТЕРАТУРЫ
}

Аристов, В. В. (1985) Казанские находки: поиски литературные и исторические. Казань : Татарское книжное изд-во. 192 с.

Аристов, В. В. (1987) Страницы славной истории: рассказы о Казанском университете. Казань : Изд-во Казанского ун-та. 222 с.

Аристов, В. В. (1992) Первое литературное общество Поволжья (К истории Казанского общества любителей общественной словесности в 1808-1818 гг.). Казань : Изд-во Казанского ун-та. 45 с.

Булич, Н. Н. (1887) Из первых лет Казанского университета (1805-1819) : [в 2 ч.]. Казань : Тип. Имп. ун-та. Ч. 1. Х, 639 с.

Вишленкова, Е. А. (2003) Казанский университет Александровской эпохи. Казань : ИзА-во Казанского ун-та. 240 с.

Гарзавина, А. В. (1987) «В Казань, профессору К. Ф. Фуксу...». Казань : Татарское книжное изд-во. 239 с.

Гарзавина, А. В., Новицкий, А. И. (1984) Моя Казань: исторический и архитектурно-художественный облик. Казань : Татарское книжное изд-во. 191 с.

Аержавин, Г. Р. (1957) Стихотворения. $\Lambda$. : Советский писатель. 468 с.

Аружинина, И. А. (2006) Изучение античности в Казанском университете, XIX - 20-е годы XX века. Казань : Изд-во Казанского ун-та. 156, с.

Загоскин, Н. П. (1902) История Императорского Казанского университета за первые сто лет его существования 1804-1904 : в 4 т. Казань : Типолитограф. Имп. Казанского ун-та. Т. 2. Ч. 2: 1814-1819. 698, XVIII, VII c.

Ибрагимов, Н. М. (1815а) О многознаменательности и общем изменении слов // Торжество Казанского общества любителей отечественной словесности Аекабря 12 дня, 1814 года. Казань : В Университетской типографии. 436 с. С. 120-129.

Ибрагимов, Н. М. (1815b) Стихи на всерадостный день рождения Киргиз-кайсацкого царевича Хлора // Торжество Казанского общества любителей отечественной словесности Аекабря 12 дня, 1814 года. Казань : В Университетской типографии. 436 с. 
Казанский университет, 1804-2004 : Биобиблиографический словарь (2002) : в 3 т. / под ред. Г. Н. Вульфсона и др. Казань : Изд-во Казанского ун-та.

Каталог книг, отпечатанных в типографии Императорского Казанского университета с 1800 по 1896 год. Б. м., б. А.

Кондырев, П. С. (1815) Историческое обозрение общества и о пользе оного // Торжество Казанского общества любителей отечественной словесности Аекабря 12 дня, 1814 года. Казань : В Университетской типографии. 436 с.

Мазитова, Н. А. (1972) Изучение Ближнего и Среднего Востока в Казанском университете (первая половина XIX века). Казань : Изд-во Казанского ун-та. 225 с.

Михайлова, С. М. (1979) Казанский университет и просвещение народов Поволжья и Приуралья (XIX век). Казань : Изд-во Казанского ун-та. 224 с.

Михайлова, С. М. (1991) Казанский университет в духовной культуре народов востока России (XIX в.). Казань : Изд-во Казанского ун-та. 359 с.

Михайлова, С. М. (1997) Развитие ориенталистики в Казанском университете в XIX в. // Казань, Москва, Петербург: Российская империя взглядом из разных углов / под ред. Б. Гаспарова и др. М. : ОГИ. 414 с. С. $275-301$.

Михайлова, С. М., Коршунова, О. Н. (2006) Казанский университет: между Востоком и Западом. Казань : Изд-во Казанского ун-та. 207 с.

Петр Сергеевич Кондырев. (2002) // Глухов-Ногайбек, М. Казанский ретро-лексикон / Казань : Изд. центр "Основа". 575 с.

Список членов Общества в начале 1817 года // Торжество Казанского общества любителей отечественной словесности Аекабря 12 дня, 1814 года. Казань : В Университетской типографии. 436 с.

Схиммельпеннинк ван дер Ойе, А. (2004) Мирза Казем-Бек и казанская школа востоковедения // Новая имперская история постсоветского пространства / ред. и сост. И. Герасимов и др. Казань : Центр исследований национализма и империй. 656 с. С. 243-270.

Устав Казанского Общества Аюбителей отечественной словесности (1815)// Торжество Казанского общества любителей отечественной словесности Аекабря 12 дня, 1814 года. Казань : В Университетской типографии. 436 с.

Федотова, О. (2006) «Желая усовершенствовать себя в отечественной словесности...»// Эхо веков. № 2 (45). С. 237-241.

Aksakov, S. (1983) A Russian schoolboy. Oxford ; N. Y. : Oxford University Press. xi, 161 p.

Andreeva, E. (2007) Russia and Iran in the great game: Travelogues and Orientalism. L. ; N. Y. : Routledge. xii, 273 p.

Bassin, M. (1999) Imperial visions: Nationalist imagination and geographical expansion in the Russian Far East, 1840-1865. Cambridge ; New York : Cambridge University Press. 329 p.

Becker, S. (1986) The Muslim East in nineteenth century Russian popular historiography // Central Asian Survey. Vol. 5. No. 3/4. P. 25-47.

Bradley, H. (1899) The Goths, from the earliest times to the end of the Gothic dominion in Spain. N. Y. : G. P. Putnam's Sons. 376 p.

Bradley, J. (2009) Voluntary associations in tsarist Russia: Science, patriotism, and civil society. Cambridge, MA : Harvard University Press. 366 p.

Brower, D. (1997) Islam and ethnicity: Russian colonial policy in Turkestan // Russia's Orient: Imperial Borderlands and Peoples, 1700-1917 / ed. by D. R. Brower, E. J. Lazzerini. Bloomington, IN : Indiana University Press. 339 p. P. 115-135.

Crews, R. (2006) For prophet and tsar: Islam and empire in Russia and Central Asia. Cambridge, MA : Harvard University Press. 463 p.

Flynn, J. T. (1988) The University reform of tsar Alexander I, 1802-1835. Washington, DC : Catholic University of America Press. 283 p.

Geraci, R. P. (2001) Window on the East: National and imperial identities in late tsarist Russia. Ithaca, NY : Cornell University Press. 389 p. 
Hagen, M. von (2007) Federalisms and pan-movements: Re-imagining empire // Russian empire: Space, people, power, 1700-1930 / ed. by J. Burbank, M. von Hagen, A. Remnev. Bloomington ; Indianapolis, IN, Indiana University Press. 538 p. P. 494-510.

Historical anthology of Kazan Tatar verse: Voices of eternity (2000) / ed. and transl. by D. J. Matthews, R. Bukharaev. Richmond, England : Curzon. 209 p.

Kappeler, A. (2001) The Russian empire: A multiethnic history. Harlow : Longman. xxiii, 455 p.

Khalid, A. (1998) The politics of Muslim cultural reform: Jadidism in Central Asia. Berkeley, CA : University of California Press. 335 p.

Khalid, A. (2000) Russian history and the debate over Orientalism // Kritika: Explorations in Russian and Eurasian History. Vol. 1. No. 4 (Fall). P. 691-699. DOI: 10.1353/kri.2008.0032

Khodasevich, V. (2007) Derzhavin: A biography / transl. and introd. by A. Brintlinger. Madison, WI : University of Wisconsin Press. $281 \mathrm{p}$.

Knight, N. (2000) Grigor'ev in Orenburg, 1851-1862: Russian Orientalism in the service of empire? // Slavic Review. Vol. 59. No. 1 (Spring). P. 74-100. DOI: 10.2307/2696905

Kosach, G. G. (1998) A Russian city between two continents: The Tatars of Orenburg and state power // Russia at a crossroads: History, memory and political practice / [editorial board: N. Schleifman]. L. ; Portland, OR : Frank Cass. 235 p. P. 33-88.

Kozelsky, M. (2009) Christianizing Crimea: Shaping sacred space in the Russian empire and beyond. DeKalb, IL : Northern Illinois University Press. 270 p.

Layton, S. (1994) Russian literature and empire: Conquest of the Caucasus from Pushkin to Tolstoy. Cambridge ; N. Y. : Cambridge University Press.354 p.

Layton, S. (1997) Nineteenth-century Russian mythologies of Caucasian savagery // Russia's Orient: Imperial borderlands and peoples, 1700-1917 / ed. by D. R. Brower, E. J. Lazzerini. Bloomington, IN : Indiana University Press. 339 p. P. 80-99.

Malte-Brun, M. [Malte-Brun, C.] (1828) Universal geography, or A description of all parts of the world, on a new plan, according to the great natural divisions of the globe ; accompanied with analytical, synoptical, and elementary tables : [in 8 vols.]. Boston : Wells and Lilly. Vol. VI. $700 \mathrm{p}$.

Martin, A. M. (1997) Romantics, reformers, reactionaries: Russian conservative thought and politics in the reign of Alexander I. DeKalb, IL : Northern Illinois University Press. 294 p.

Mohrenschildt, D. von (1981) Toward a United States of Russia: Plans and projects of federal reconstruction of Russia in the nineteenth century. Rutherford, NJ : Fairleigh Dickinson University Press. 309 p.

Ostrowski, D. (2004) Kazan // Encyclopedia of Russian History : in 4 vols. / editor-in-chief J. R. Millar. New York : Macmillan Reference. Vol. 2: E-L. 425-882 p.

Ram, H. (2006) The imperial sublime: A Russian poetics of empire. Madison, WI : University of Wisconsin Press. $x, 307$ p.

Robinson, O. W. (1992) Old English and its closest relatives: A survey of the earliest Germanic languages. Stanford, CA : Stanford University Press. 290 p.

Rorlich, A.-A. (1986) The Volga Tatars: A profile in national resilience. Stanford, CA : Hoover Institution Press, Stanford University. 288 p.

Ruud, C. A. (1982) Fighting words: Imperial censorship and the Russian press, 1804-1906. Toronto : University of Toronto Press. $327 \mathrm{p}$.

Said, E. (1979) Orientalism. N. Y. : Vintage Books. 368 p.

Schwab, R. (1984) The Oriental Renaissance: Europe's rediscovery of India and the East, 1680-1880. N. Y. : Columbia University Press. 542 p.

Smith-Peter, S. (2004) How to write a region: Local and regional historiography // Kritika: Explorations in Russian and Eurasian History. Vol. 5. No. 3 (Summer). P. 527-542. DOI: 10.1353/ kri.2004.0046

Whittaker, C. H. (1978) The impact of the Oriental Renaissance in Russia: The case of Sergej Uvarov // Jahrbücher für Geschichte Osteuropas. Bd. 26. No. 4. P. 503-524. 
Wiener, L. (1902) Anthology of Russian Literature from the earliest period to the present time. N. Y. ; L. : G. P. Putnam's Sons. 523 p.

Wolff, L. (1994) Inventing Eastern Europe: The map of civilization on the mind of the Enlightenment. Stanford, CA : Stanford University Press. xiv, 419 p.

Wortman, R. (1995) Scenarios of power: Myth and ceremony in Russian Monarchy : in 2 vols. Princeton, NJ : Princeton University Press. Vol. 1: From Peter the Great to the death of Nicholas I. 469 p.

Аата поступления: 16.01.2016 2.

Smith-Peter Susan, PhD, Associate Professor, Department of History, College of Staten Island, City University of New York. Postal address: Room 204, Bldg. 2N, 2800 Victory Blvd., Staten Island, NY 10314, USA. Tel.: (+1) 718-982-3290 Email: susan.smithpeter@csi.cuny.edu

Смит-Питер Сьюзен - доктор философии (PhD), доцент кафедры истории, колледж Стейтен-Айленд, Городской университет Нью-Йорка, США. Почтовый адрес: Room 204, Bldg. 2N, 2800 Victory Blvd., Staten Island, NY 10314, USA. Тел.: (+1) 718-982-3290 Эл. адpec: susan.smithpeter@csi.cuny.edu 